\title{
Rotura extremo piélico de catéter doble J incrustado
}

\section{Traumatic break of ureteral stent}

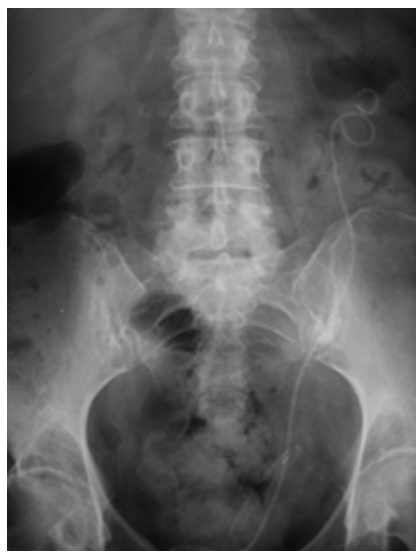

Figura 1 - Rotura del extremo piélico en el mismo acto que obligó a colocar nuevo doble J izquierdo.

J.M. Abascal Junquera*, M. Hevia Suárez, J.M. Abascal García y R. Abascal García

Servicio de Urología II, Hospital Universitario Central de Asturias, Oviedo, España

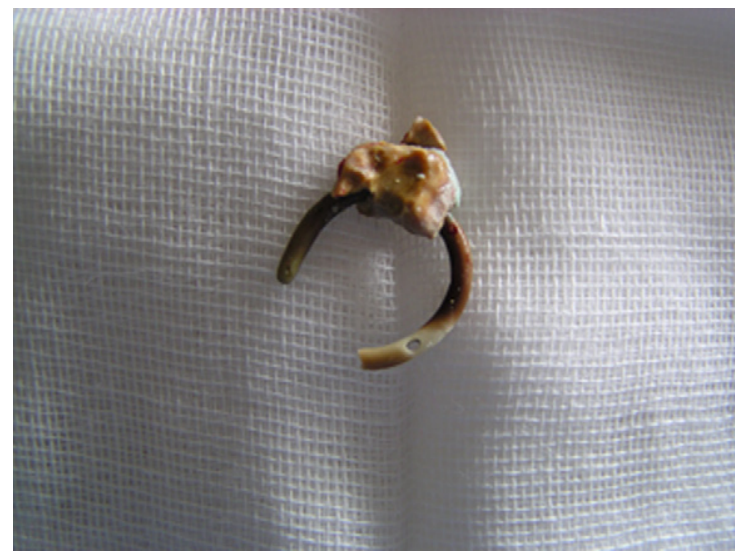

Figura 2 - Retirada del extremo piélico del catéter doble J con incrustación mediante acceso percutáneo, tras intento sin éxito en el mismo acto de retirada vía retrógada con ureterorrenoscopio.

*Autor para correspondencia.

Correo electrónico: josuvargas@hotmail.com (J.M. Abascal Junquera).

doi: 10.1016/j.acuro.2010.02.063

\section{Litiasis en ectopia renal cruzada sin fusión}

\section{Lithiasis in cross renal ectopy without fusion}
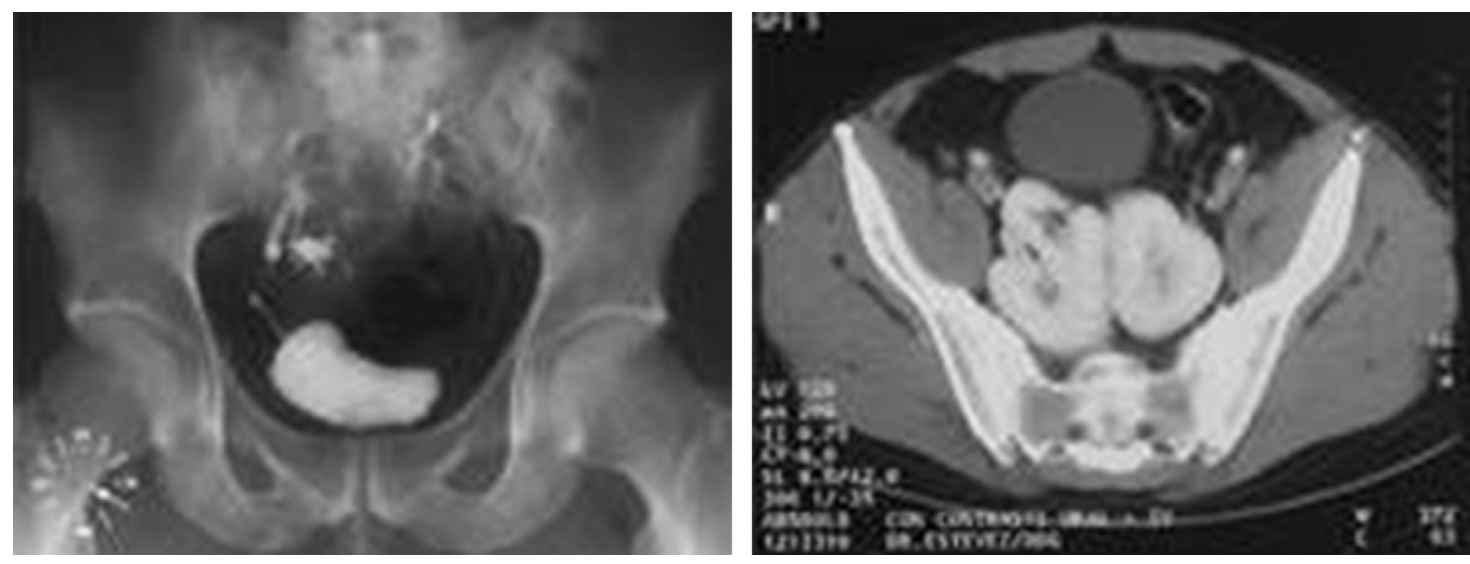

Figuras 1 y 2 - La urografía intravenosa muestra ambos riñones intrapélvicos que captan y eliminan contraste, y una imagen litiásica en uréter proximal derecho de aproximadamente $5 \mathrm{~mm}$ que provoca mínima extasia pielocalicial. El TAC confirma estos hallazgos.

M.A. Arrabal Polo*, M. Arrabal Martín, F. Valle Diaz de La Guardiã y A. Zuluaga Gómez
*Autor para correspondencia.

Correo electrónico: arrabalp@ono.com (M.A. Arrabal Polo). doi: 10.1016/j.acuro.2010.02.064 